\title{
Epiphytic Microalgal Species Composition and Dynamics on Host Green Seaweeds (Ulvaphyceae) on the Northern Coast of Jeddah, Saudi Arabia
}

\author{
Salim Marzoog Al-Harbi \\ Department of Marine Biology, College of Marine Sciences, King Abdulaziz University, Saudi Arabia
}

Copyright $(2017$ by authors, all rights reserved. Authors agree that this article remains permanently open access under the terms of the Creative Commons Attribution License 4.0 International License.

\begin{abstract}
Epiphytic microalgae on seaweeds are sessile microscopic plants grown with attached or associated to seaweeds hosts and seaweeds are multicellular and macroscopic macro-algae, which are abundant in intertidal zones of coastal environments. Study on epiphytic microalgae is rare at Jeddah coast of the Red Sea. Thus, an investigation on epiphytic microalgae species composition and dynamics on seaweeds of Ulvaphyceae was carried out at northern coast of Jeddah, the Red Sea. The Red Sea is narrow oceanic basin which is lying between the African and the Asian continental shelves. During the study, 3 species of seaweeds were recorded in Ulvaphyceae which were Chaetomorpha linum, Enteromorpha intestinalis and Ulva lactuca. A total of 70 epiphytic microalgae were identified, including 63 belong to Bacillariophyceae, 5 belong to Cyanophyceae and 2 belong to Dinophyceae. Among the identified epiphytic microalgae of the host seaweeds of Ulvaphyceae, the percent contribution of epiphytic Bacillariophyceae, Cyanophyceae and Dinophyceae were $91.53,6.55$ and $2.61 \%$, respectively. The cell abundance of epiphytes on host seaweeds of Ulvaphyceae varied from 8.00 to 93.00 cells/ cells/100 g of Ulvaphyceae seaweeds. The highest cell abundance was in spring and the lowest was in summer. On host seaweeds of Ulvaphyceae, the epiphytes of Licmophora abbreviata, Gyrosigma fasciola, Leptocylindrus danicus, Navicula distans, Navicula transitans, Pleurosigma angulatum and Pleurosigma normanii, Thalassionema frauenfeldii and Nitzschia hungarica were above $10 \%$ among epiphytic microalgae though Amphora spp., and Cocconeis spp., were found throughout the year. This finding could be the important source for future explanation of marine epiphytes and their host seaweed eco-biogeographical phenomena in the Red Sea.
\end{abstract}

Keywords Seaweeds Ulvaphyceae, Epiphytic Microalgae, Seasonal Dynamics, Environmental Factors, Northern Jeddah Coast

\section{Introduction}

Epiphytic microalgae on seaweeds are sessile microscopic plants grown with attached or associated to seaweeds hosts. Seaweeds are multicellular and macroscopic macro-algae, which are abundant in intertidal zones of coastal environments. Primarily they grow in near-shore coastal waters with suitable substrates for attachment [1]. Seaweeds are usually distributed in intertidal and subtidal zones of coastal waters. Seaweed is one of the best growing plants worldwide. It does not require irrigation or fertilizers, and it does not require arable land. Marine Seaweeds play significant roles in the normal functioning of atmospheric environments even though seaweeds are restricted to the tide zones and benthic photic zones [1]. They contribute to about $10 \%$ of the total world marine productivity. Ecologically they account for food and shelter for marine life. They play an important role in the coastal carbon cycle and contribute remarkably to sea-farming activities. The rate of primary production of some species is comparable with those of the most productive land plants. The microalgae grow attached or associated to other plants known as epiphyton, epiphytes or epiphytic microalgae [2]. The leaves and stems of seaweeds provide substrates suitable for the attachment and growth of various numbers of microalgae [3]. Epiphytic flora attach on host tissue such as leaves of seaweeds with loosely or tightly attached or adnate component $[4 ; 5]$. Epiphytic microalgae are common constituents of aquatic systems and they are important in terms of productivity [6], and a suitable food source for higher trophic levels [7; 8] .The dynamics, abundance and community structure of epiphytic microalgae are influenced by biotic factors such as leaf age, seasonal cycle of the host, and grazing pressure by herbivores, and also by the light, temperature, nutrients and water motion [3; $9 ; 10]$. The abundant and diverse of epiphytic microalgae include diatoms, dinoflagellates and cyanobacteria which make a significant contribution to food webs.

However, the study on seaweeds and microalgae association is rare at the coast of the Red Sea, Saudi Arabia. 
The Red Sea is a unique area in the tropics. It is considered the highest saline water body in the world's seas with the deep water salinity of $40.06 \mathrm{psu}$ and surface water salinity ranged from 40.10 to $40.65 \mathrm{psu}[11 ; 12]$. The high salinity phenomenon occurs due to its location in an arid and hot climatic zone, isolation from open sea, without riverine inputs, the high evaporation rate $\left(>210 \mathrm{~cm} \mathrm{yr}^{-1}\right)$ and scant rainfall. The Red Sea surface waters pile up from December to February along the African coast and some upwelling occurs along the Arabian coast [11], and reversal of summer condition because of the south-southeast winds only affect the southern half of the Red Sea. These two circulation patterns seasonally converge and surface waters sink at Jeddah Coast. Downwelling reduces biological productivity and transports heat, dissolved materials, and dissolved oxygen rich surface waters in to greater depths. The convergence zone is classified as the poorer zone in microalgae species [13]. There are few reports on water column microalgal ecology, community composition and primary productivity, diatom composition in marine fouling at Jeddah Coast $[14 ; 15 ; 16]$. There is a single study on seasonal dynamics of epiphytic microalgae and their host seaweeds Florideophyceae at the southern coast of Jeddah [17]. Different groups of seaweeds except Florideophyceae and their epiphytes have not been studied along the Jeddah coast. In this study, Ulvaphyceae and their epiphytes association have been studied in details at the northern coast of Jeddah. Therefore, this study was conducted with objectives to make systematic account for the seaweeds species of Ulvaphyceae and their epiphytic microalgae abundant, seasonal composition at northern coast of Jeddah.

\section{Materials and Methods}

\section{Study Area, Sampling and Sample Analysis}

The sampling was done seasonally at the peak of season which was in March (spring), June (summer), September (autumn) and December (winter) in 2015. The sampling was conducted at the northwest coast of Jeddah, Saudi Arabia, the Red Sea. The sampling sites were; (i) Yambu $\left(23^{\circ} 59^{\prime} 45^{\prime \prime} \mathrm{N}\right.$ and $38^{\circ} 10^{\prime} 35^{\prime \prime} \mathrm{E}$ ) is one of major sea port of the Red Sea in the Al Madinah province of western Saudi Arabia. It is approximately 300 kilometers northwest of Jeddah. There are oil refineries and petrochemical industry. (ii) Ar-Rayis $\left(23^{\circ} 33^{\prime} 55^{\prime \prime} \mathrm{N}\right.$ and $\left.38^{\circ} 36^{\prime} 17^{\prime \prime} \mathrm{E}\right)$ is an industrial city of Madinah province (iii) Mastura $\left(23^{\circ} 08^{\prime} 80^{\prime \prime} \mathrm{N}\right.$ and $38^{\circ}$ $\left.47^{\prime} 14^{\prime \prime} \mathrm{E}\right)$ is famous for fishing, (iv) Rabigh $\left(22^{\circ} 41^{\prime} 35^{\prime \prime} \mathrm{N}\right.$ and $39^{\circ} 00^{\prime} 34^{\prime \prime} \mathrm{E}$ ) has several industries such as a factory of cement, electricity station, large refinery, Petro Rabigh and (v) Thuwal $\left(22^{\circ} 16^{\prime} 44^{\prime \prime} \mathrm{N}\right.$ and $\left.39^{\circ} 05^{\prime} 21^{\prime \prime} \mathrm{E}\right)$ had long been a fishing center. The town is experiencing an increase in industries due to its proximity to the King Abdullah Economic City (Figure 1). Seaweeds samples were collected randomly from the above mentioned sites. The wet seaweeds leaves (except stalk and rhizoids) were kept in polyethylene bags and transferred to laboratory. Hundred grams wet sea weeds were put in plastic bottle with filtered seawater, and separation of epiphytic algae from their host was performed by manual shaking method described by [18]. Then, the epiphytic microalgal samples were preserved with $2 \%$ of logul's solution for further study. For taxonomical study, the sample was observed under the phase-contrast microscope (Zeiss Axioplan, Germany) at 400x magnification. Taxonomic identifications were made with reference to [19; $20 ; 21 ; 22 ; 23 ; 2]$. For quantitative study, a $1 \mathrm{~mL}$ sample was taken after mixing of the preserved sample and counted in a Sedgewick-Rafter (S-R) counter chamber with same microscope as mentioned above. Counted results were summarized as cells per 100 grams of seaweeds, and used for graphical presentation. The water temperature, salinity and $\mathrm{pH}$ were measured on spot with portable meter $\mathrm{HACH}$ (Model HQ14d).

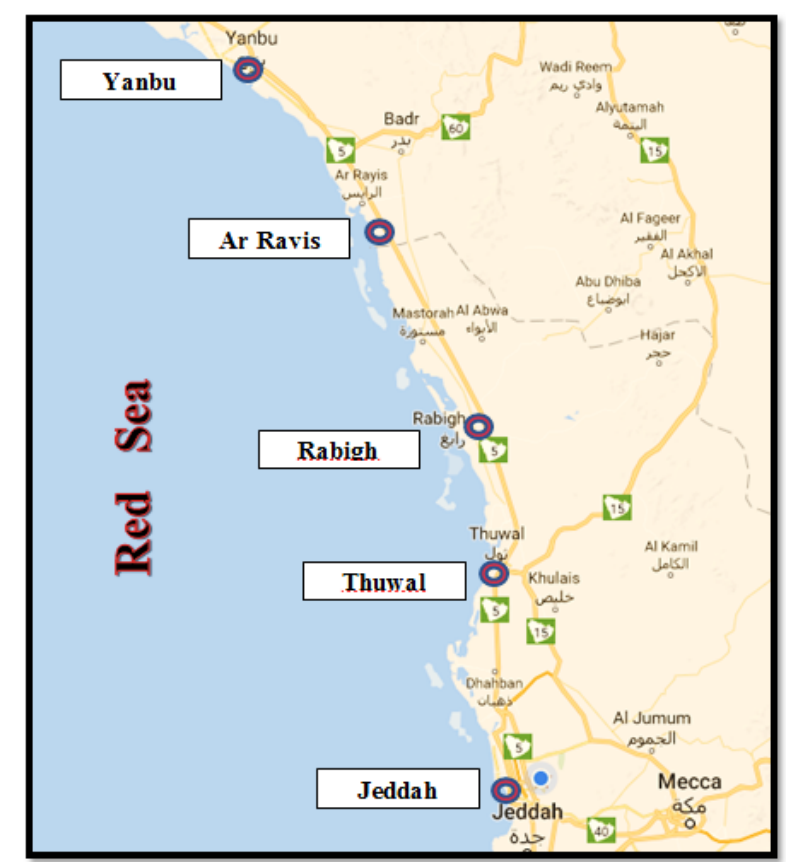

Figure 1. Location of the study sites; Northwest coast of Jeddah, Saudi Arabia, namely Yambu, Ar-Rayis, Mastorah, Rabigh and Thuwal, the Red Sea.

\section{Results}

\section{Dynamics of Physical Factors}

The water temperature was found to be highest in summer-autumn. Temperature varied from 22.10 to $32.02^{\circ} \mathrm{C}$ with an average of $28.48^{\circ} \mathrm{C}$. The minimum and maximum temperatures were in winter and summer at Yambu and Rabigh, respectively (Figure 2.). Salinity fluctuated from 38.72 to 39.35 psu with an average of $38.92 \mathrm{psu}$. The lowest salinity was in spring at Ar-Rayis and the highest was in summer at Yambu (Figure 3). The $\mathrm{pH}$ varied from 8.40 to 8.63 throughout the study with an average of 8.52.The highest and the lowest $\mathrm{pH}$ was recorded at Rabigh and Mastorah in spring and summer, respectively. The high $\mathrm{pH}$ was in spring, followed by winter among all the stations (Figure. 4). 


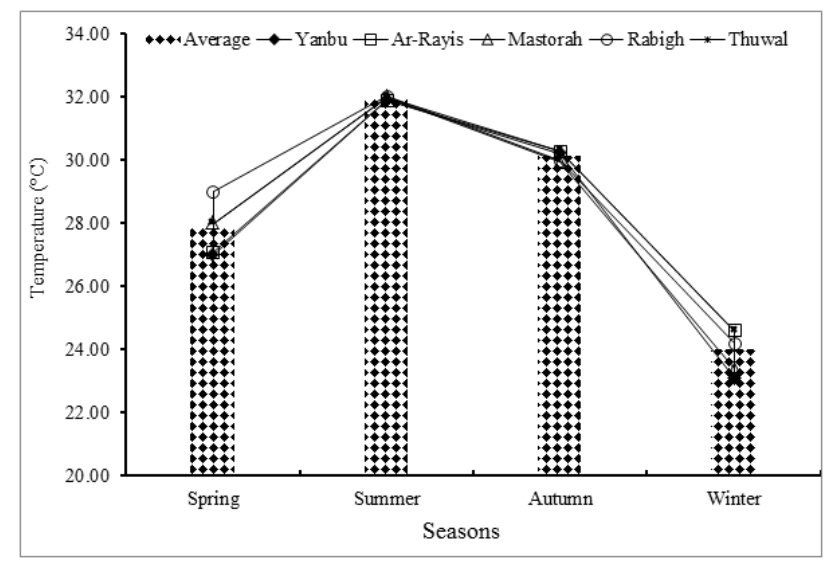

Figure 2. Seasonal variation of water temperature $\left({ }^{\circ} \mathrm{C}\right)$ at the Northwest coast of Jeddah, namely Yambu, Ar-Rayis, Mastorah, Rabigh and Thuwal, the Red Sea, Saudi Arabia from spring to winter 2015.

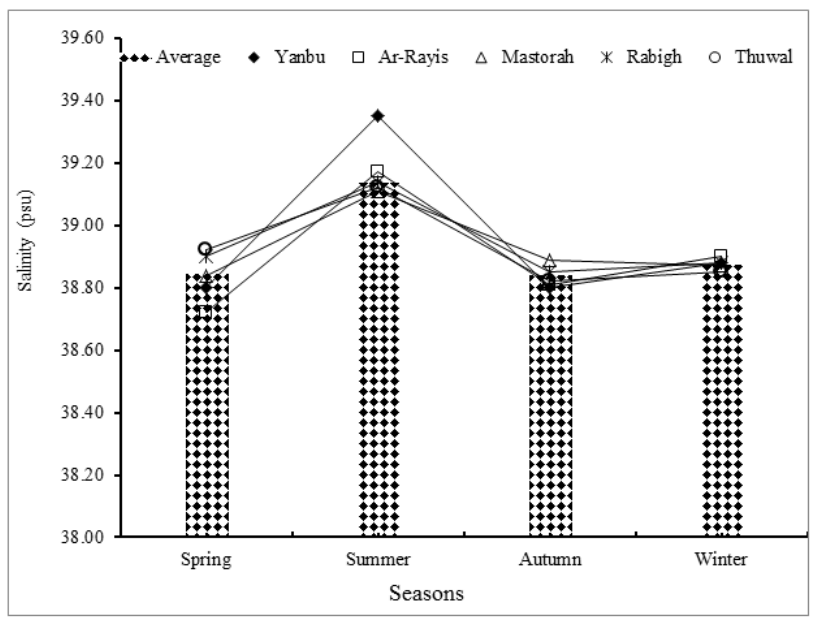

Figure 3. Seasonal variation of salinity (psu) at the Northwest coast of Jeddah, namely Yambu, Ar-Rayis, Mastorah, Rabigh and Thuwal, the Red Sea, Saudi Arabia from spring to winter 2015.

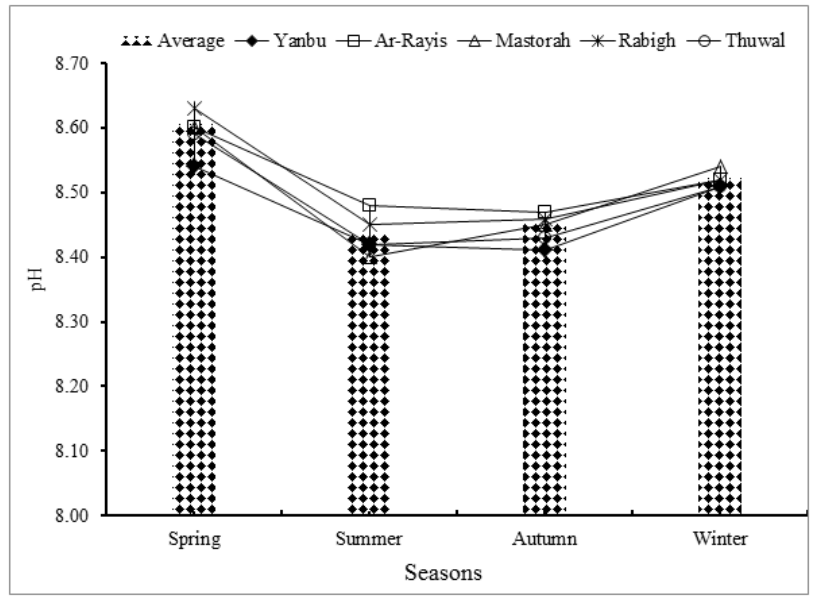

Figure 4. Seasonal variation of $\mathrm{pH}$ at the at the Northwest coast of Jeddah, namely Yambu, Ar-Rayis, Mastorah, Rabigh and Thuwal, the Red Sea, Saudi Arabia from spring to winter 2015.

\section{Composition and Dynamics of Seaweeds and Epiphytes}

Seaweeds and Epiphytic Microalgal Species Composition

A total of 3 species of Ulvaphyceae such Chaetomorpha linum, Enteromorpha intestinalis and Ulva lactuca were found throughout the year among different sites. Chaetomorpha linum and Enteromorpha intestinalis were found in four seasons at stations Mastorah and Rabigh. Ulva lactuca was found in winter, spring and autumn at Rabigh and Mastorah (Table 1.). A total of 70 epiphytic microalgae were identified, including 63 belong to Bacillariophyceae, 5 belong to Cyanophyceae and 2 belong to Dinophyceae. Among the identified epiphytic microalgae of the host seaweeds of Ulvaphyceae, the percent contribution of epiphytic Bacillariophyceae, Cyanophyceae and Dinophyceae were $91.53,6.55$ and $2.61 \%$, respectively (Table 3). The cell abundance of epiphytes on host seaweeds of Ulvaphyceae varied from $8.00 \times 10^{5}$ to $95.00 \times 10^{5}$ cells $/ 100$ $\mathrm{g}$ of Ulvaphyceae seaweeds (Figure 5.). The highest cell abundance was in spring and the lowest was in summer. The cell abundance of epiphytes on host seaweeds of Enteromorpha intestinalis varied from $23.00 \times 10^{5}$ to $52.00 \times 10^{5}$ cells $/ 100 \mathrm{~g}$ of Enteromorpha intestinalis with an average of $38.00 \times 10^{5}$ cells $/ 100 \mathrm{~g}$ of Enteromorpha intestinalis. The highest and lowest epiphytic cell abundance was found in winter and summer, respectively (Figure 5.). On host seaweeds of Enteromorpha intestinalis, the epiphytes of Chaetoceros fragile, Gyrosigma fasciola, Leptocylindrus danicus, Navicula distans, Navicula transitans, Pleurosigma angulatum and Pleurosigma normanii was above $10 \%$ among epiphytic microalgae. Leptocylindrus danicus, Pleurosigma angulatum and Pleurosigma normanii was 56, 21 and 20\%, respectively among epiphytes (Table 3). Similarly, the abundance of epiphytes on seaweeds of Chaetomorpha linum varied from $12 \times 10^{5}$ to $69.38 \times 10^{5}$ cells $/ 100 \mathrm{~g}$ of Chaetomorpha linum, with an average of $30.00 \times 10^{5}$ cells $/ 100 \mathrm{~g}$ of Chaetomorpha linum (Figure 5). The cell abundance of Leptocylindrus danicus, Navicula distans, Nitzschia hungarica and Thalassionema frauenfeldii was above $10 \%$ among epiphytes on seaweeds of Chaetomorpha linum (Table 2). The epiphytes cell abundance on seaweeds Ulva lactuca varied from $8.00 \times 10^{5}$ to $95.00 \times 10^{5}$ cells $/ 100 \mathrm{~g}$ of Ulva lactuca, and the average cell abundance of that epiphytic microalgae was $63.00 \times 10^{5}$ cells $/ 100 \mathrm{~g}$ of Ulva lactuca (Figure 5). Four species of epiphytes cell abundance were found to be above $10 \%$ among epiphytes. Licmophora abbreviata contributed highest percent among the composition of epiphytes which was $53 \%$, followed by Thalassionema frauenfeldii (31\%) and Pleurosigma normanii (24\%) (Table 3). 
Table 1. List of seaweeds found at different sites of northern coast of Jeddah, Saudi Arabia, namely Yanbu, Ar-Riyas, Mastorah, Rabigh and Thuwal, the Red Sea from spring to winter 2015.

\begin{tabular}{|c|c|c|c|c|}
\hline Ulvophyceae & Winter & Spring & Summer & Autumn \\
\hline Chaetomorpha linum Müller & $\mathrm{M}, \mathrm{R}$ & $\mathrm{M}, \mathrm{R}$ & $\mathrm{R}$ & $\mathrm{R}$ \\
\hline Enteromorpha intestinalis Linnaeus & $\mathrm{R}, \mathrm{M}$ & $\mathrm{R}$ & $\mathrm{R}$ & $\mathrm{R}, \mathrm{M}$ \\
\hline Ulva lactuca Linnaeus & $\mathrm{R}, \mathrm{M}$ & $\mathrm{R}, \mathrm{M}$ & - & $\mathrm{R}$ \\
\hline
\end{tabular}

*Legend of location; M, Mastorah; R, Rabigh; T, Thuwal; Ar-Riyas; and Y, Yanbu.

Table 2. List of epiphytic microalgal taxa, frequency of occurrence and percent (\%) contribution of each class on the seaweeds Ulvaphyceae at the northern coast of Jeddah from winter to autumn, 2015.

\begin{tabular}{|c|c|c|c|c|c|}
\hline \multirow[t]{2}{*}{ Phytoplankton species name } & \multicolumn{4}{|c|}{ Seasons } & \multirow[b]{2}{*}{$\%$} \\
\hline & Winter & Spring & Summer & Autumn & \\
\hline Bacillariophyceae & & & & & 91.53 \\
\hline Achnanthes longipes Agardh & & $\mathrm{X}$ & $\mathrm{X}$ & $\mathrm{C}$ & \\
\hline Amphiprora alata Ehrenberg & $\mathrm{C}$ & & & & \\
\hline A. hyperborean Grunow & & & $\mathrm{R}$ & & \\
\hline A. paludosa Smith & & $\mathrm{X}$ & $\mathrm{X}$ & & \\
\hline A. arcus Gregory & & & $\mathrm{C}$ & & \\
\hline A. coffeaeformis Grunow & & $\mathrm{R}$ & $\mathrm{X}$ & $\mathrm{F}$ & \\
\hline A. commutatum Grunow & & $\mathrm{X}$ & $\mathrm{R}$ & & \\
\hline Bacillaria paxillifera Müller & $\mathrm{H}$ & $\mathrm{C}$ & $\mathrm{C}$ & & \\
\hline Biddulphia alternan Bailey & & & $\mathrm{C}$ & & \\
\hline B. oduntella Greville & & $\mathrm{X}$ & & & \\
\hline Chaetoceros brevis Schütt & $\mathrm{H}$ & $\mathrm{X}$ & & & \\
\hline C. socialis Lauder & & $\mathrm{X}$ & $\mathrm{X}$ & & \\
\hline Closterium Navicula Brébisson & & & & $\mathrm{X}$ & \\
\hline Cocconeis ceticola Nelson & & & & $\mathrm{X}$ & \\
\hline C. pediculus Ehrenberg & & $\mathrm{R}$ & & & \\
\hline C. placentula Ehrenberg & & & $\mathrm{X}$ & & \\
\hline C. scutellum Ehrenberg & & $\mathrm{R}$ & $\mathrm{R}$ & & \\
\hline Coscinodiscus lineatus Ehrenberg & & $\mathrm{X}$ & & & \\
\hline C. granii Gough & & & $\mathrm{R}$ & & \\
\hline C. minor Ehrenberg & & & $\mathrm{R}$ & & \\
\hline C. radiatus Ehrenberg & $\mathrm{C}$ & $\mathrm{X}$ & $\mathrm{X}$ & $\mathrm{X}$ & \\
\hline Cyclotella meneghiniana Kützing & & & & $\mathrm{X}$ & \\
\hline Cylindrotheca closterium Ehrenberg & & $\mathrm{H}$ & $\mathrm{R}$ & $\mathrm{C}$ & \\
\hline Entomoneis paludosa Smith & & & & $\mathrm{R}$ & \\
\hline Grammatophora oceanica Ehrenberg & & & & $\mathrm{X}$ & \\
\hline Gyrosigma lineare Cleve & $\mathrm{C}$ & $\mathrm{X}$ & & & \\
\hline G. acuminatum Kützing & $\mathrm{C}$ & & & $\mathrm{X}$ & \\
\hline G. fasciola Ehrenberg & & & & $\mathrm{F}$ & \\
\hline G. obtusatum Wormley & $\mathrm{C}$ & $\mathrm{X}$ & & & \\
\hline Lauderia annulata Cleve & & $\mathrm{X}$ & $\mathrm{R}$ & & \\
\hline Leptocylindrus adriaticus Schroder & & $\mathrm{X}$ & & & \\
\hline L. danicus Cleve & $\mathrm{C}$ & $\mathrm{F}$ & $\mathrm{R}$ & $\mathrm{X}$ & \\
\hline L. minimus Gran & $\mathrm{C}$ & $\mathrm{C}$ & $\mathrm{C}$ & $\mathrm{R}$ & \\
\hline Licmophora abbreviata Agardh & & $\mathrm{X}$ & $\mathrm{X}$ & $\mathrm{R}$ & \\
\hline L. flabellata Greville & $\mathrm{C}$ & $\mathrm{X}$ & $\mathrm{R}$ & $\mathrm{H}$ & \\
\hline
\end{tabular}


Epiphytic Microalgal Species Composition and Dynamics on Host Green Seaweeds (Ulvaphyceae) on the Northern Coast of Jeddah, Saudi Arabia

\begin{tabular}{|c|c|c|c|c|c|}
\hline L. gracilis Ehrenberg & & & $\mathrm{X}$ & & \\
\hline L. grandis Kützing & $\mathrm{C}$ & $\mathrm{F}$ & & $\mathrm{X}$ & \\
\hline L. paradoxa Lyngbye & $\mathrm{C}$ & & & $\mathrm{X}$ & \\
\hline Navicula delicatula Cleve & $\mathrm{C}$ & $\mathrm{C}$ & $\mathrm{C}$ & $\mathrm{C}$ & \\
\hline N. distans Smith & $\mathrm{C}$ & & $\mathrm{C}$ & $\mathrm{F}$ & \\
\hline N. fastuosa Ehrenberg & & & & $\mathrm{X}$ & \\
\hline N. granii Jørgense & $\mathrm{C}$ & & & & \\
\hline N. gregaria Navicula gregaria & & $\mathrm{X}$ & & & \\
\hline$N$. incerta Grunow & & $\mathrm{R}$ & & & \\
\hline N. transitans Cleve & $\mathrm{H}$ & $\mathrm{F}$ & $\mathrm{X}$ & $\mathrm{H}$ & \\
\hline Nitzschia delicatissima Cleve & & $\mathrm{X}$ & & & \\
\hline N. seriata Cleve & & $\mathrm{X}$ & $\mathrm{R}$ & & \\
\hline N. socialis Gregory & & $\mathrm{X}$ & $\mathrm{R}$ & & \\
\hline N. delicatissima Ndeli & & $\mathrm{X}$ & & & \\
\hline Pinnularia gibba Ehrenberg & $\mathrm{C}$ & & & $\mathrm{F}$ & \\
\hline Pleurosigma angulatum Quekett & $\mathrm{H}$ & $\mathrm{R}$ & $\mathrm{F}$ & $\mathrm{C}$ & \\
\hline P. elongatum Smith & $\mathrm{C}$ & $\mathrm{X}$ & & & \\
\hline P. normanii Ralfs & $\mathrm{H}$ & $\mathrm{F}$ & $\mathrm{R}$ & $\mathrm{H}$ & \\
\hline Rhizosolenia sp., Smith & & $\mathrm{X}$ & & $\mathrm{X}$ & \\
\hline$R$. Brightwell & & $\mathrm{X}$ & $\mathrm{X}$ & $\mathrm{F}$ & \\
\hline Skeletonema costatum Greville & $\mathrm{C}$ & & & & \\
\hline Striatella unipunctata Lyngbye & & $\mathrm{C}$ & & & \\
\hline Synedra ulna Nitzsch & & & & $\mathrm{F}$ & \\
\hline Tabellaria fenestrate Lyngbye & $\mathrm{C}$ & & & & \\
\hline T. flocculosa Kützing & $\mathrm{C}$ & $\mathrm{X}$ & $\mathrm{F}$ & & \\
\hline Thalassionema bacillare Heiden & & $\mathrm{X}$ & $\mathrm{C}$ & & \\
\hline T. frauenfeldii Grunow & & $\mathrm{X}$ & $\mathrm{X}$ & $\mathrm{H}$ & \\
\hline T. nitzschioides Grunow & $\mathrm{C}$ & $X$ & $\mathrm{C}$ & & \\
\hline Dinophyceae & & & & & 2.61 \\
\hline Prorocentrum lima Ehrenberg & & $\mathrm{F}$ & $\mathrm{R}$ & & \\
\hline Cerataulina bergonii Peragallo & $\mathrm{C}$ & & & & \\
\hline Cyanophyceae & & & & & 6.65 \\
\hline Chroococcus turgidus (Kützing & & $\mathrm{X}$ & $\mathrm{X}$ & & \\
\hline Oscillatoria sp. Gomont & & $\mathrm{X}$ & & & \\
\hline Merismopedia sp. Kützing & & & & $\mathrm{X}$ & \\
\hline Spirulina subsalsa Gomont & & $\mathrm{C}$ & $\mathrm{R}$ & $\mathrm{C}$ & \\
\hline Microcystis aeruginosa Kützing & & & $\mathrm{R}$ & $\mathrm{C}$ & \\
\hline
\end{tabular}

*Legend of occurrence frequency: Sporadically ( $\mathrm{X}=1-20 \%)$, Rarely $(\mathrm{R}=21-40 \%)$, Commonly $(\mathrm{C}=41-60 \%)$, Frequently $(\mathrm{F}=61-80 \%)$ and High Frequently $(\mathrm{H}=81-100 \%)$. 
Table 3. List of epiphytic microalgal taxa, frequency of occurrence and percent (\%) contribution of each class on the seaweeds Ulvaphyceae at the northern coast of Jeddah from winter to autumn, 2015.

\begin{tabular}{|c|c|c|c|c|c|}
\hline Ulvophyceae & Epiphytes & Winter & Spring & Summer & Autumn \\
\hline & & $\%$ & $\%$ & $\%$ & $\%$ \\
\hline \multirow{4}{*}{ Chaetomorpha linum } & Leptocylindrus danicus & 34 & & & \\
\hline & Navicula distans & & 18 & & \\
\hline & Nitzschia hungarica & & & & 16 \\
\hline & Thalassionema frauenfeldii & & 40 & & \\
\hline \multirow{7}{*}{ Enteromorpha intestinalis } & Chaetoceros fragile & & & 11 & \\
\hline & Gyrosigma fasciola & & & & 10 \\
\hline & Leptocylindrus danicus & 56 & 11 & & \\
\hline & Navicula distans & & & 13 & \\
\hline & Navicula transitans & & & 11 & \\
\hline & Pleurosigma angulatum & & & & 20 \\
\hline & Pleurosigma normanii & & 10 & & 21 \\
\hline \multirow{4}{*}{ Ulva lactuca } & Licmophora abbreviata & 53 & 14 & & 17 \\
\hline & Licmophora flabellata & 19 & & & \\
\hline & Pleurosigma normanii & & & & 24 \\
\hline & Thalassionema frauenfeldii & & 31 & & \\
\hline
\end{tabular}

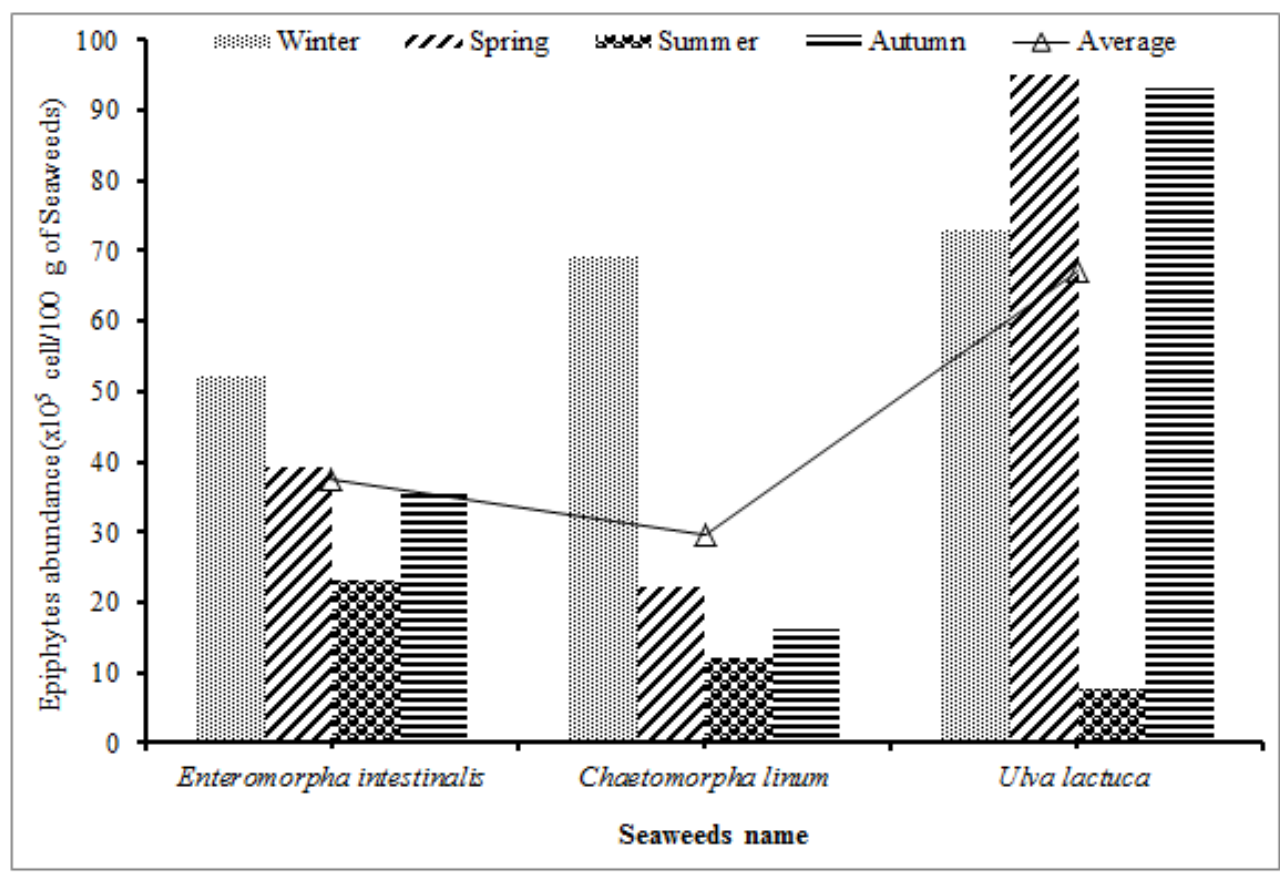

Figure 5. Variation of epiphytes cell abundance associated with seaweeds of Ulvaphyceae available at northwest coast of Jeddah from winter to autumn 2015 .

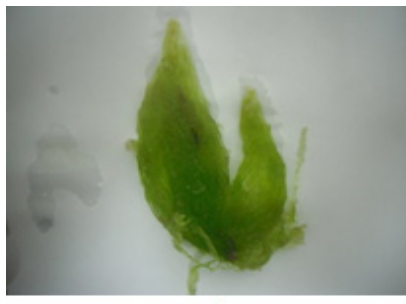

A

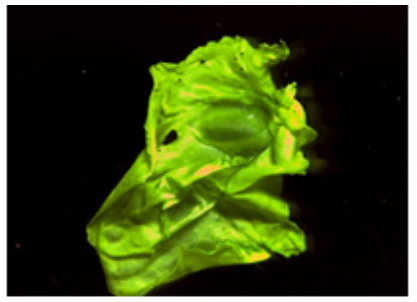

B

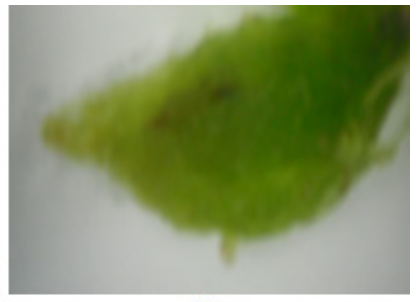

$\mathrm{C}$

Figure 6. Enteromorpha sp.sp. (A), Ulva lactuca sp. (B) and Chaetomorpha linum sp. (C) 


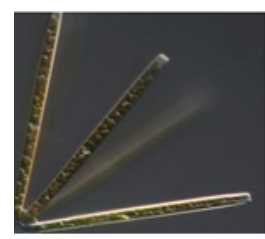

A

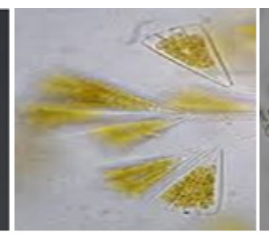

B

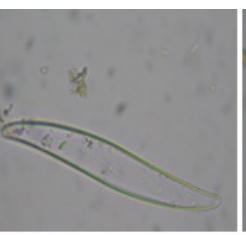

$\mathrm{C}$

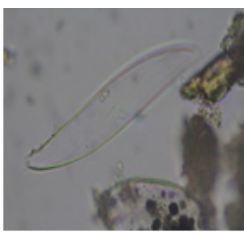

D

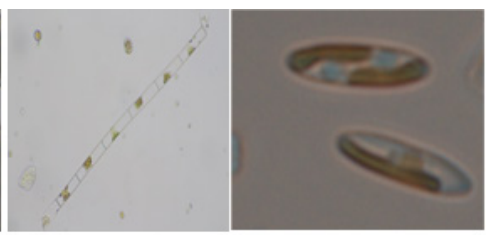

E
F

Figure 7. Thalassionema sp. (A), Licmophora sp. (B), Pleurosigma sp. (C), Gyrosigma sp. (D) Leptocylindrus sp. (E) and Navicula sp. (F).

\section{Discussion}

Three species of seaweeds of Ulvaphyceae were found throughout the year at the northern coast of Jeddah, the Red Sea. These species were available at Mastorah and Rabigh, and they were more in winter and spring. Those species found at different seasons and different area which made different habitats for epiphytic microalgae depending on local environmental conditions (nutrient, substratum, current, etc.). The epiphytic abundance and composition were also found to be varied due to the variation of presence of seaweeds in different area with different seasons. This might be the results of the interaction between the lifespan of the host and the reproductive lifespan of the epiphytes [24] although environmental factors and predators control the abundance of epiphytic microalgae.

In this study, 2 species of seaweeds among 3 species of Ulvaphyceae were found in four seasons as host for epiphytic microalgae. Among the epiphytes, 91.43\% was diatoms (Bacillariophyceae). These long life span seaweeds might have provided substrate for diatoms species for long time for highest occurrence and abundance diatoms. Vegetated ecosystems are ideal habitats for benthic diatoms and other epiphytes as seaweeds leaves and thalli may provide greater surface area for the colonization and growth of diatoms [25]. [26] reported that diatoms and bacteria were the primary organisms which made colony on the submerged objects and they shape a biofilm. Therefore, it could be said that seaweeds species of Ulvaphyceae might be the suitable substrate for diatoms in winter and spring at Mastorah and Rabigh.

Diatoms were the most dominant epiphyte though some also from Dinophyta and Cyanophyta. Diatoms have advantage over other group of epiphytes because of their high fucoxanthin content. Fucoxanthin is known as the most efficient photosynthetic carotenoid absorbing light in the green waveband [27]. Thus, diatoms become dominant on the seaweeds in coastal waters with effect of available of blue light. The blue light can rapidly attenuated with preferential transmission of the green-to- yellow wavelengths for photosynthesis [28]. Among the epiphytic smaller diatoms, the genera of Licmophora sp, Cocconeis spp., Navicula spp., Amphora spp., and Nitzschia spp., were found more frequently throughout the year. Therefore, it could be assumed that those smaller diatoms might have got suitable substance from the seaweeds of Ulvaphyceae for proliferation and dominant at the northern coast of Jeddah, the Red Sea.

There is evidence that tube forming species of Navicula, Nithzschia and Amphora are epiphytes as they create cells masses within a gelatinous matrix [2]. Thus, the species which showed $10 \%$ or more abundance among the microalgae found on the leaves of seaweeds of Ulvaphyceae can consider as real epiphytic microalgae though they occurred in different seasons on same or different genus of seaweeds of Ulvaphyceae. [29] found that the reasons for a specific dependency of epiphytic microalgae on the substratum might be related with the shape of the thalli surface. The diatoms with small attaching area like Licmophora $\mathrm{sp}$, is predominant on fine branched thalli while think branched thalli are preferred by diatoms with a large attaching area like Cocconeis sp., and tube living diatoms like Navicula sp., [29]. In this study, the seaweeds of Ulvaphyceae having larger and branched thalli which provided suitable substratum for small and large attaching diatoms. Therefore, it could be assumed that those smaller diatoms might be obligatory to grow or might have got suitable substance and surface area on leaves of the seaweeds of Ulvaphyceae at the northern coast of Jeddah, the Red Sea. Thus, it can be said that seaweeds of Ulvaphyceae might have provide favorable circumstance in the high saline water of the Red Sea to those species of epiphytes which were found frequently and also some times as dominant species.

\section{Conclusions}

The host seaweeds influenced the facilitated diatoms growth through its morphology and surface texture and roughness, providing a point of attachment and shelter. The seaweeds were collected from intertidal zone where the water depth was around half meter. Three species seaweeds of Ulvaphyceae were found at the study area during the study period. Most of the dominant epiphytes were in smaller cell size diatoms, especially Licmophora spp., Navicula spp., Amphora spp., Cocconeis spp., throughout the year. The findings of the study focused on the need for further, long-term and spatially extensive investigations to gather the necessary information about individual species of benthic marine diatoms associated with specific seaweeds species even in different seasons in different regions of the Red Sea, Saudi Arabia. These findings could be the important source for future explanation of marine epiphytes and their host seaweed eco-biogeographical phenomena in the Red Sea. 


\section{Acknowledgements}

This project was funded by the Deanship of Scientific Research (DSR), King Abdulaziz University, Jeddah, under grant no. 468/150/1434. The authors, therefore, acknowledge with thanks DSR technical and financial support.

\section{REFERENCES}

[1] Murphy, S., Eunice, H., Pinn., Paul D. J. 2013. Theshort-beaked common dolphin (Delphinus delphis) in thenorth-east Atlantic: distribution, ecology, management and conservation status. Oceanography and Marine Biology: An Ann. Rev. 51: 193-280.

[2] Round, F. E., Crawford, R. M. and Mann, D. G. 1990. The diatoms: biology \& morphology of the genera. Cambridge University press, Cambridge, $747 \mathrm{pp}$.

[3] Mazzella, L. and Russo, G. F. 1989. Grazing effect of two Gibbula species (Mollusca, Archaeogastropoda) on the epiphytic community of Posidonia oceanica leaves," Aquatic Botany, 35: 357-373.

[4] Burkholder, J. M., Wetzel, R. G. 1990. Epiphytic alkaline phosphatase on natural and artificial plants in an oligotrophic lake: re-evaluation of the role of macrophytes as a phosphorus source for epiphytes. Limnol. Oceanogr. 35: 736-747.

[5] Cattaneo, A. and Kalff, J. 1978. Seasonal changes in the epiphyte community of natural and artificial macrophytes in Lake Memphremagog (Que. and Vt.). Hydrobiologia 60, 135-144.

[6] Burkholder, J. M., Wetzel, R. G., Komparens, K. L. 1990. Direct comparison of phosphate uptake by adnate and loosely attached microalgae within an intact biofilm matrix. Appl. Environ, Microbiol. 56: 2882-2890.

[7] Kitting, C. L., Fry, B., Morgan, M. D. 1984. Detection of inconspicuous epiphytic algae supporting food webs in seagrass meadows. Oecologia, 62: 145-149.

[8] Sullivan, M. J., Moncreiff, C. A. 1990. Edaphic algae are an important component of salt marsh food-webs: evidence from multiple stable isotope analyses. Mar. Ecol. Prog. Set. 62:149-159.

[9] Prado, P., Alcoverro, T., Mart'inez-Crego, B., Verg'es, M. A., P'erez, and Romero, J. 2007. Macrograzers strongly influence patterns of epiphytic assemblages in seagrass meadows," Journal of ExperimentalMarine Biology and Ecology, 350: 130-143.

[10] Mabrouk, L., Hamza, A., Brahim, M. B. and Bradai, M. N. 2011. Temporal and depth distribution of microepiphytes on Posidonia oceanica (L.) Delile leaves in a meadow off Tunisia. Marine Ecology, 32: 148-16.

[11] Marcos SA (1970) Physical and chemical oceanography of the Red Sea. Oceanogr Mar Biol Ann Rev 8: 73-202.

[12] Manasrah R, Badran M, Lass HU, Fennel WG (2004) Circulation and winter deep-water formation in the northern Red Sea. Oceanol 46: 5-23.

[13] Halim Y (1984) Plankton of the Red Sea and the Arabian Gulf.
Deep-Sea Res II 31: 969-982.

[14] Aleem, A. A. 1978. Contributions to the study of the marine algae in the Red Sea. III. Marine algae from Obhur in the Vicinity of Jeddah, Saudi Arabia. Bull Facul Sci KAU Jeddah 2: 99-118.

[15] Khomayis, H. S. 2002. The annual cycle of nutrient salts and chlorophyll a in the coastal waters of Jeddah, Red Sea. J. KAU: Mar Sci., 13: 131-145.

[16] Khomayis, H. S., Harbi, S. M. A. 2003. Pcriphyton flora in the coastal water of Jeddah, Saudi Arabia. J. KAU: Mar Sci., $14: 3-18$

[17] Harbi, S. M. A and Affan, M. A. 2016. Seasonal dynamics of epiphytic microalgae and their host seaweeds florideophyceae at jeddah coast, the Red sea, Saudi Arabia. Pak. J. Bot., 48:1289-1298.

[18] Gosselain, V., Hudon, C., Cattaneo, A., Gagnon, P., Planas, D., and Rochefort, D. 2005. Physical variables driving epiphytic algal biomass in a dense macrophyte bed of the St. Lawrence River (Quebec, Canada). Hydrobiologia, 534: 1122.

[19] Prescott, G.W., 1973. Algae of the western Great Lakes Area. Dubuque, W.C Brown.

[20] Tomas CR (1993) Marine Microalgae, a guide to naked flagellates and coccolithophorids. Academic Press, Harcourt Brace, San Diego, California, USA.

[21] Tomas CR (1997) Identifying marine microalgae. Academic Press, Harcourt Brace, San Diego, California, USA.

[22] Shim, J. H. 1994. Illustrated encyclopedia of fauna and flora of Korea, vol. 34 Marine microalgae. Ministry of Education, Seoul, Korea.

[23] Kobayasi, H., Idei, M., Mayama, S., Nagumo, T. and Osada K., Kobayasi's, H., 2006. Atlas of Japanese Diatoms based on electron microscopy. Vol.1. Uchida Rokakuho Publishing Co. Ltd., Tokyo.

[24] Borowitzka, M.A., Lavery, P., Keulen, M., 2006. Epiphytes of seagrasses," in Seagrasses:Biology, Ecology and Conservation, A. W. D. Larkum, R. J. Orth, and C. M. Duarte, Eds., Springer, Amsterdam, The Netherlands.

[25] Zieman, J.C., Fourqurean, J.W., and Iverson, R.L., 1989. Distribution, abundance and productivity of seagrasses and macroalgae in Florida Bay. Bulletin of Marine Science 44: 292-311.

[26] Novak, R. 1984. A Study in Ultra-Ecology: Microorganisms on the Seagrass Posidonia oceanica (L.) Delile. Pubblicazione de,lla Stazione Zoologica di Napoli I : Marine Ecology 5: 143-190.

[27] Ondrusek, M.E., Bidigare, R.R., Sweet, S.T., Defreitas, D.A., and Brooks, J.M., 1991. Distribution of phytoplankton pigments in the North Pacific Ocean in relation to physical and optical variability. Deep-sea Research 38: 243-266.

[28] Gin, K.Y.H., Zhang, S. and Lee, Y.K., 2003. Phytoplankton community structure in Singapore's coastal waters using HPLC pigment analysis and flow cytometry. Journal of Plankton Research 25: 1507-1519.

[29] Ramm, G. 1976. Structure of epiphytic diatom populations of the phytal of the Kiel Bight (Western Baltic). In: Simonsen R. (ed.), Proceedings of Fourth Symposium on Recent and Fossil Marine Diatoms. Ganter Verlag KG, Germany. pp. 379-387. 